\title{
CYP2A7 wt Allele
}

National Cancer Institute

\section{Source}

National Cancer Institute. CYP2A7 wt Allele. NCI Thesaurus. Code C116971.

Human CYP2A7 wild-type allele is located in the vicinity of $19 q 13.2$ and is approximately 7 $\mathrm{kb}$ in length. This allele, which encodes cytochrome P450 2A7 protein, may be involved in both the oxidation of steroids, fatty acids and xenobiotics and the NADPH-dependent electron transport pathway. 